\title{
Circulating endothelial cells and endothelial progenitor cells in childhood primary angiitis of the central nervous system D Eleftheriou*1, LA Clarke ${ }^{1}$, Y Hong ${ }^{1}$, NJ Klein ${ }^{2}$, V Ganesan ${ }^{3}$ and PA Brogan ${ }^{1}$
}

Address: ${ }^{1}$ Rheumatology Department, Institute of Child Health, London, UK, ${ }^{2}$ Infectious Diseases and Microbiology Unit, Institute of Child Health, London, UK and ${ }^{3}$ Neurology Department, Institute of Child Health, London, UK

* Corresponding author

from I5th Paediatric Rheumatology European Society (PreS) Congress

London, UK. 14-17 September 2008

Published: 15 September 2008

Pediatric Rheumatology 2008, 6(Suppl I):P276 doi:I0.I 186/I546-0096-6-SI-P276

This abstract is available from: http://www.ped-rheum.com/content/6/SI/P276

(c) 2008 Eleftheriou et al; licensee BioMed Central Ltd.

\section{Background}

Primary angiitis of the central nervous system in children (cPACNS) is an inflammatory vasculitis that solely affects the CNS vessels in the absence of a systemic inflammatory process. Circulating endothelial cells (CECs) are increasingly described as biomarkers for tracking vascular injury [1]. Additionally, bone marrow-derived endothelial progenitor cells (EPCs) are thought to play a pivotal role in the regeneration of damaged endothelium. We describe the relationship of CECs and EPCs to clinical and/or radiological disease progression in CPACNS.

\section{Materials and methods}

16 children, median age 7 years old (range 1.8-17); 9 males with cPACNS were studied. Two groups were identified, according to radiological and/or clinical progression, or non progression at $>6$ months from diagnosis. CECs were isolated from whole blood using immunomagnetic bead extraction. EPCs were detected using flow cytometry and were defined as mononuclear cells triple positive for CD34/CD133/CD144 and CD34/CD133/ VEGFR2.

\section{Results}

Median CEC count in progressive cPACNS was significantly raised to $480 / \mathrm{ml}(176-1152)$ compared to $36 / \mathrm{ml}$ $(0-168)$ in non-progressive disease $(\mathrm{p}=0.0007), 32 / \mathrm{ml}$ $(0-152)$ in child control $(\mathrm{p}=0.0050)$ and $24 / \mathrm{ml}(16-$ 141 ) in patients with non inflammatory cerebrovascular pathology $(\mathrm{p}=0.0016)$. CD34+CD133+CD144+ cells were significantly raised in patients with progressive dis- ease compared to child controls $(\mathrm{p}=0.005)$ and patients with non progressive disease $(\mathrm{p}=0.03)$. There was a similar but non significant trend for EPCs expressing CD34/ CD133/VEGFR2.

\section{Conclusion}

CECs can be used to track vascular injury due to cPACNS and differentiate progressive versus non-progressive cerebral vasculitis. We also demonstrated an increase in EPCs in progressive cPACNS, perhaps indicative of a compensatory reparative vasculogenic response.

\section{References}

I. Clarke LA, Shah V, Arrigoni F, Eleftheriou D, Hong Y, Halcox J, Klein NJ, Brogan PA: Quantitative detection of circulating endothelial cells in vasculitis: comparison of flow cytometry and immunomagnetic bead extraction. J Thromb Haemost 2008, 6:1025-1032 